\title{
Vetenskap och tro - två halvor av samma hjärna?
}

\section{Emilie Wellfelt}

I september 2008 publicerade Sydsvenskan.se nyheten: Per Eriksson blir rektor för Lunds universitet (Thunell 2008). Några timmar senare infördes en läsarkommentar med rubriken "Man undrar". Signaturen Fundersams inlägg lydde: "Vad anser den frireligiöse Eriksson om kreationism, intelligent design, skapelseberättelsen i bibeln, stamcellsforskning, evolution $\mathrm{m} \mathrm{m}, \mathrm{m}$ m??" (Sydsvenskan.se 2008-09-26). Inlägget kan betraktas som startskottet för en het debatt. När det blev allmänt känt att nye universitetsrektorn var före detta pingstvän som numera tillhörde Hyllie Park-kyrkan och var medlem i Evangeliska frikyrkan, då var det många som kritiserade tillsättningen. Grunden i kritiken var frågan om tro och vetenskap går att förena.

Lärare på universitetets naturvetenskapliga fakultet hörde till dem som protesterade högljutt. Ett argument lydde: "Pingstkyrkan är ju en rätt extrem vetenskapsfientlig rörelse" (Fagerström \& Thunell, 2008). Själv kommenterade den blivande rektorn "Jag har en kritisk vetenskaplig grundsyn, och för övrigt tror jag på religionsfrihet” (Sydsvenskan.se 2008).

80 år tidigare, 1928, upptäckte den indiske fysikern C.V. Raman ljusets oelastiska spridning, den så kallade Ramaneffekten. 1930 renderade detta ett Nobelpris i fysik (The Nobel foundation 1930). Vad har lundarektorn och nobelpristagaren gemensamt? Kanske sin syn på vetenskap och tro. Om Raman berättas att han vid ett tillfälle rusade hem från sitt laboratorium i Calcutta för att hinna med ett rituellt bad innan en solförmörkelse inträffade. När detta ifrågasattes lär Raman ha svarat att "Nobelpriset, det var vetenskap, men en solförmörkelse, det är personligt" (Chakrabarty 2008[2000]).

Berättelsen om nobelpristagaren har publicerats av den marxistiska historikern Dipesh Chakrabarty $i$ boken Provincializing Europe, Postcolonial thought and historical difference. Chakrabarty tolkar indisk historia ur ett postkolonialt perspektiv, men med analysredskap som är hämtade från västerländsk tradition. Ett dilemma han möter är sättet som mänsklig aktivitet i en indisk kontext länkas samman med närvaro och agerande av gudar eller andar. Gudar med egen vilja hör inte hemma i vetenskapliga historiska arbeten, så vad gör man om de envisas med att dyka upp i källmaterialet? Hur ska man, till exempel, i en historiematerialistisk analys hantera Hathiyar puja, dyrkan av verktyg, som firas i många nordindiska fabriker? (Chakrabarty 2008 [2000]: 76 ff., 95 f.).

En möjlighet är att, som Chakrabarty gjort (1989), se tillbedjan av maskiner, allt från taxibilar till svarvar, som motsvarigheten till att teckna en försäkring. Men han är uppenbart otillfredsställd av att reducera tro till funktion. Varför har han sådana dubier? Chakrabarty pekar mot sitt eget förflutna. I ett nytillkommet förord till senaste upplagan (2008 [2000]) av Provincializing Europe berättar Chakrabarty att han under sin uppväxt i en bengalisk medelklassfamilj i Calcutta aldrig funderade speciellt över begreppet Europa. Han föddes efter självständigheten 1947, men arvet efter det brittiska kolonialväldet, fanns överallt runt honom. Allt från trafikregler och skoluniformer till kritik mot kastsystemet och arrangerade äktenskap kunde härledas dit. Myten om Europa var högst närvarande i Indien efter kolonialtiden.

Marx tog stor plats i det intellektuella samtalet under 1960- och 1970-talen, så även i Indien. Med sina vänner drack den unge Chakrabarty te och diskuterade huruvida indiska kapitalister skulle betraktas som en nationell bourgeoisie eller om de var en klass underställd det interna- 
tionella kapitalet. Utan att tveka diagnostiserade de feodala attityder hos folk i sin omgivning. Begreppen användes utan analys, eftersom man redan visste vad de betydde. Den självklarheten försvann när Chakrabarty började studera historia. Vardagsorden problematiserades när de blev redskap för professionell historiematerialistisk samhällsanalys. 1976 flyttade Chakrabarty till Australien för sin forskarutbildning, som var inriktad på Sydasien. Han har inte varit bosatt i Indien sedan dess. Chakrabarty blev en av redaktörerna bakom de vetenskapliga tidskrifterna Subaltern studies och Postcolonial Studies.

Den historia han velat lyfta fram är de undertrycktas, de marginaliserades. Om man har den ambitionen, hur ska man då förhålla sig till att de man identifierat som undertryckta, till exempel bönderna i Santalupproret 1855, hävdar att de agerade på uppmaning av guden Thakur? Ska böndernas egen version avfärdas som strunt? Kanske inte, men den kan inte heller forma en vetenskaplig analys av upproret, menar Chakrabarty (2008 [2000]: 103, 105f.).

Chakrabarthy har ingen patentlösning på problemet. Han hävdar tvärtom att det inte finns någon möjlighet att förena Santalledarnas syn med historikerns. Det finns dock ett par alternativa sätt att hantera saken. Ett är att definiera sig själv som ett modernt subjekt vars studieobjekt är Santalbönderna och deras livssituation. Resultatet blir en studie där man söker förklaringar till upproret 1855. Det andra alternativet är att lösa upp tidsväven och inta ståndpunkten att böndernas agerande har betydelse idag, att det kan ge vägledning för oss som lever nu. Chakrabarty hävdar att historieskrivande kräver en sådan inlevelse. Först måste man förstå, sedan kan man distansera sig och söka förklaringar (Chakrabarty 2008 [2000]: 108ff., 112).

Chakrabartys första substantiella bidrag till indisk historieskrivning var Rethinking WorkingClass History: Bengal 1890-1940 (1989). Boken om arbetarhistoria i Bengalen bottnar i ungdomens diskussioner om proletariatets världshistoriska roll i ett land som domineras av jordbruk snarare än industri. Under arbetets gång började Chakrabarty ifrågasätta de teoretiska grunderna för arbetet. Går det att ta idéer som bottnar i europeiska förhållanden och applicera dem på andra platser?

Författaren beskriver hur han upplevde två steg av distansering. Dels ett historiskt objektivt perspektiv på det skeende han analyserade, dels en närmast parodisk känsla av att kränga på karaktärer ur bengalisk och indisk historia kostymer som inte riktigt ville passa, eftersom det var "European costumes lent by the Marxist drama of history" (Chakrabarty 2008 [2000]).

Den egna erfarenheten av migration, från Indien till Australien, har stor betydelse för det problem som Chakrabarty tampas med, nämligen hur tanke är relaterat till plats och tid; att leva i olika världar som vägrar fusionera. Som ett slags tröst lyfter han fram indiska vetenskapsmän som inte valt mellan världarna, utan rört sig i båda. Nobelpristagaren Raman som sprang hem för rituell tvagning när det var solförmörkelse är ett exempel. En annan känd indier var matematiker, astronom och samtidigt astrolog. När sonen undrade hur fadern kunde läsa ur hinduiska texter med sådan religiös inlevelse, för att senare samma dag tala uppskattande om Bertrand Russel eller den amerikanske religionskritikern Ingersoll, svarade fadern: "Vet du inte att hjärnan har två lober?" (Chakrabarty 2008 [2000]: 253).

Uppenbarligen hade varken nobelpristagaren i fysik eller den kände matematikern problem med att husera motsägelser inom sig. De båda hjärnloberna, eller skillnaden mellan vetenskap och det personliga, är enligt Chakrabarty exempel på olika sätt att se tid och att förhålla sig till historia. Ett slags historia handlar om att analysera orättvisor. Ett annat slags historia handlar om olika sätt att vara människa (Chakrabarty 2008 [2000]: 254). 
Chakrabartys dilemma är förhållandet tro och rationalitet. Kanske finns också ett slags lojalitetskonflikt mellan hans intellektuella förebilder och de undertryckta människor som han vill ge röst åt. Det intellektuella arv han refererar till kommer i första hand från europeiska tänkare, men han har svårt att få de europeiska kostymerna att passa indiska aktörer. Problemet belyser han genom att lyfta fram Ranajit Guha (1983) och dennes kritik av Eric Hobsbawm (1978 [1959]). När Hobsbawm kategoriserar 1900-talets sociala rörelser som "arkaiska" och tredje världens bönder som "prepolitiska", är varken Guha eller Chakrabarty med på tåget (Chakrabarty 2008 [2000]: 11-16).

Det finns två linjer i Chakrabartys kritik av västerländsk historiesyn. Dessa löper som röda trådar genom Provincializing Europe. En är synen på modernitet och utveckling, där bönderna i tredje världen blir anakronismer. De är arkaiska reminiscenser som med tiden kommer att utvecklas åt ett bestämt håll. Detta evolutionistiska synsätt är implicit eller explicit en markör för tredje världens "inte ännu"-skap, att folk utanför västvärlden inte är moderna ännu. Synsättet präglar, enligt Chakrabarty, även självsynen hos många representanter för tredje världens intellektuella. Men, har Guha (1983) argumenterat, Indiens bönder var under den aktuella perioden (1900-tal) inte anakronismer i en moderniserande kolonial värld, utan lika samtida som kolonialismen och utgjorde en fundamental del i den modernitet som kolonialstyret förde med sig i Indien.

Den andra linjen i Chakrabartys kritik riktar in sig på hur Hobsbawm tolkat bönders uppror som arkaiskt på grund av att det organiserades utifrån släktskap, religion och kast samt involverade gudar, andar och övernaturliga fenomen som aktörer utöver människorna. Chakrabarty vill inte offra gudarna och andarna på rationalitetens altare. I frågan om att vara människa inkluderar han, med hänvisning till Heidegger, frågan om att vara med gudar och andar. Annorlunda uttryckt ingår det $i$ att vara människa möjligheten att upptäcka ett behov av gud eller gudar utan att vara förpliktigad att först fastställa deras existens. Den monoteistiske guden har kanske haft sina motgångar under det senaste århundradet, resonerar Chakrabarty, men vidskeplighet har aldrig dött ut någonstans där det finns människor. Moderna människor behöver inte ha bestämd religionstillhörighet, men de fortsätter att tro på saker som inte kan bevisas (2008 [2000]: 16).

Vad är då hans tips till den som ska analysera en bonderevolt i Indien, som enligt bönderna själva skett på uppmaning av deras gud/gudar? Att översätta gudarnas vilja med en världslig förklaring, ett underliggande missnöje, ligger nära till hands. Men, säger Chakrabarty (2008 [2000]: 89): "The question is: How do we conduct these translations in such a manner as to make visible all the problems of translating diverse and enchanted worlds into the universal and disenchanted language of sociology?" Hur ska man översätta förtrollade världar till vetenskap utan att något väsentligt går förlorat i översättningen?

Chakrabartys dilemma kring vetenskap och tro är långt från unikt. Det visar bland annat debatten efter rektorstillsättningen i Lund hösten 2008. Går det en gräns mellan tro och vetenskap? Kan man ha en kritisk vetenskaplig grundsyn och samtidigt vara troende?

Min egen forskning i Indonesien rör människor som inte drar någon skiljelinje mellan synligt och osynligt. De lever i högsta grad i en besjälad värld - utan att vara medeltidsmänniskor. Detta måste jag förhålla mig till. Jag ser inga entydiga svar i Chakrabartys resonemang, men om jag identifierar mig som sekulariserad svensk historiker läser jag in ett förslag, nämligen möjligheten att vända på perspektiven. I mitt fall genom att låta tro vara den självklara utgångspunkten.

För Chakrabarty ger Marx analytiska redskap till abstraktion och till att belysa sociala orättvisor. Den andra teoretiska inriktningen som attraherar honom är hermeneutiken, med betoning på 
existentiell filosofi à la Heidegger. Där, menar Chakrabarty, får tanke och olika former av mänsklig samhörighet plats. Marx och Heidegger är som hjärnans två halvor, en som distanserar och analyserar, och den andra som söker sig in i ett myller av möjligheter.

\section{Referenser}

Chakrabarty, D., 1989, Rethinking Working-Class History: Bengal 1890-1940, Princeton: Princeton University Press.

Chakrabarty, D., 2008 [2000], Provincializing Europe, Postcolonial thought and historical difference, Princeton: Princeton University Press.

"Department of History, the University of Chicago, Dipesh Chakrabarty, Biography" http://history.uchicago.edu/faculty/chakrabarty.html 2009-03-19

Fagerström, E., Thunell, C. 2008, 'Lärare protesterar mot val av rektor", Sydsvenskan.se 2008-10-03, http://sydsvenskan.se/utbildning/article374726.ece

Guha, R., 1983, Elementary aspects of peasant insurgency in colonial India, Delhi: Oxford University Press.

Hobsbawm, E. J., 1978 [1959], Primitive Rebels: Studies in Archaic Forms of Social Movement in the 19th and 20th Centuries, Manchester: Manchester University Press.

Sydsvenskan.se, 2008, "Tre kommentarer från Per Eriksson", osignerad artikel på Sydsvenskan.se, publ. 2008-10-03, http://sydsvenskan.se/lund/article374725/Tre-kommentarer-fran-Per-Eriksson.html

Sydsvenskan.se, 2008, 'Man undrar", kommentar till artikel publicerad på Sydsvenskan.se 2008-09-26, http://sydsvenskan.se/lund/article372305/Han-blir-Lunds-nya-rektor.html?articleTab=comments

The Nobel foundation, 1930, "Sir Venkata Raman, The Nobel prize in physics 1930", http://nobelprize.org/nobel_prizes/physics/laureates/1930/raman-bio.html

Thunell, C., 2008, 'Han blir Lunds nya rektor", Sydsvenskan.se, 2008-09-26, http://sydsvenskan.se/lund/article372305/Han-blir-Lunds-nya-rektor.html 